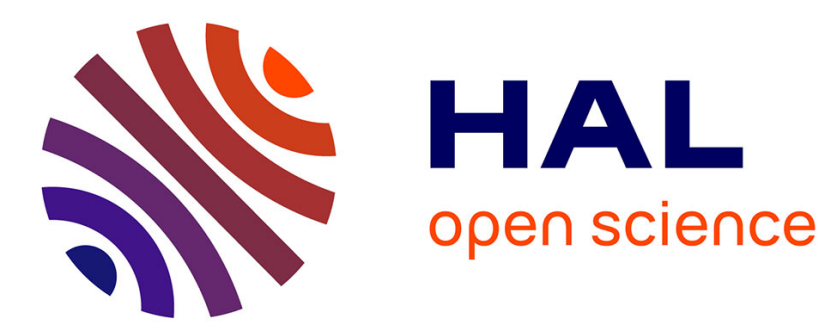

\title{
Chemodivergent, Tunable, and Selective Iodine(III)-Mediated Bromo-Functionalizations of Polyprenoids
}

Tatyana Grayfer, Pascal Retailleau, Robert H Dodd, Joëlle Dubois, Kevin Cariou

\section{To cite this version:}

Tatyana Grayfer, Pascal Retailleau, Robert H Dodd, Joëlle Dubois, Kevin Cariou. Chemodivergent, Tunable, and Selective Iodine(III)-Mediated Bromo-Functionalizations of Polyprenoids. Organic Letters, 2017, 19 (18), pp.4766-4769. 10.1021/acs.orglett.7b02125 . hal-02307207

\section{HAL Id: hal-02307207 \\ https://hal.science/hal-02307207}

Submitted on 7 Oct 2019

HAL is a multi-disciplinary open access archive for the deposit and dissemination of scientific research documents, whether they are published or not. The documents may come from teaching and research institutions in France or abroad, or from public or private research centers.
L'archive ouverte pluridisciplinaire HAL, est destinée au dépôt et à la diffusion de documents scientifiques de niveau recherche, publiés ou non, émanant des établissements d'enseignement et de recherche français ou étrangers, des laboratoires publics ou privés. 


\title{
Chemodivergent, Tunable and Selective Iodine(III)-Mediated Bromo-functionalizations of Polyprenoids.
}

\author{
Tatyana D. Grayfer, Pascal Retailleau, Robert H. Dodd, Joëlle Dubois and Kevin Cariou* \\ Institut de Chimie des Substances Naturelles, CNRS UPR 2301, Université Paris-Sud, Université Paris-Saclay, Avenue de la \\ Terrasse, 91198 Gif-sur-Yvette, France.
}

\section{Supporting Information Placeholder}

\begin{abstract}
Mild oxidation of bromides by iodine(III) reagents generated active electrophilic bromination species that were reacted with polyprenoids. By simple and minor variations of an I(III)/Br combination the reactivity could be selectively steered toward dibromination, oxybromination or bromocyclization, giving access to a wide array of brominated motifs.
\end{abstract}

Brominated terpenoids of marine origin constitute a particularly wide class of natural products that exhibit a vast array of structural diversity ${ }^{1}$ and potential therapeutic applications. ${ }^{2}$ A myriad of motifs, arising from diverse biosynthetic pathways, ${ }^{3}$ can be found in different families and sometimes in the same molecule. For example, just considering the brominated moieties of the bromophycolide $\mathrm{A}^{4}$ macrocycle (1, Figure 1$)$, fragments arising from a carbobromination, a hydroxybromination and an acyloxybromination (with the opposite regiochemistry) of a geranyl-geranyl chain can be delineated. A carbobromination accounts for the formation of cyclocymopol $2^{5}$ but in this case the double bond lies out of the ring. Isocymobarbatol $\mathbf{3}^{6}$ stems from the same linear precursor but through a formal cascade cyclization, resulting in a tricyclic scaffold. This variability could be explained by the intermediacy of one or several halogenating enzymes, ${ }^{3}$ but raises complex chemo-, regio- and stereoselectivity issues, which remain challenging for organic chemists. One way to address this challenge is to design specific reagents for one transformation, as shown by Snyder with the development of bromocyclization specific BDSB reagent. ${ }^{7,8}$

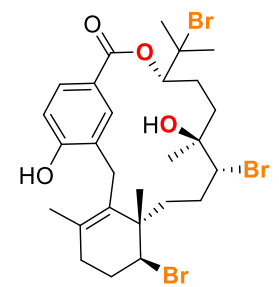

Bromophycolide A, 1

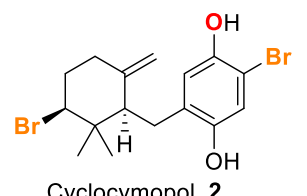

Cyclocymopol, 2

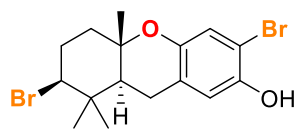

4-Isocymobarbatol, 3
Figure 1 Examples of brominated terpenoids of marine origin.

For our part we thought that it would be highly desirable to design a general strategy that would demand only limited modifications of the modus operandi to completely deviate the reactivity in one or another chemical direction. Based on our previous experi- ence $^{9}$ with iodine(III)-mediated bromination reactions ${ }^{10}$ we believed that when generating the active bromination species by in situ oxidation of a bromide by a hypervalent iodine(III) species ${ }^{11}$ several parameters would be easily tunable so as to govern the selectivity of the reaction. Thus, running the reaction in a non-participating solvent in the absence of external nucleophile should favor bromocyclization $^{9 \mathrm{~d}}$ towards bromocyclohexenyl 5 (Scheme 1, eq 1 ), while adding an alcohol to the reaction mixture would trigger an oxybromination ${ }^{9 \mathrm{a}}$ towards alkyl-bromohydrine $\mathbf{6}$ (Scheme 1, eq 2).

Scheme 1 Chemoselective iodine(III)-mediated bromination of a geranyl derivative.

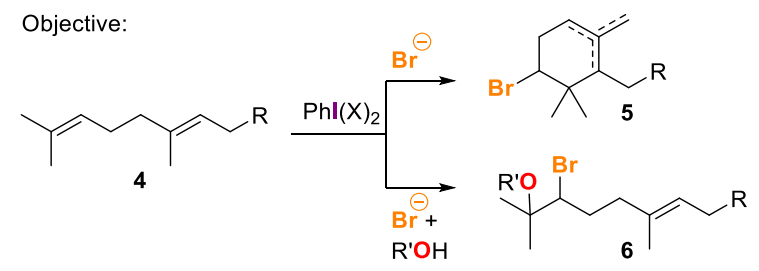

Initial experiments were performed on geranyl acetate $\mathbf{4 a}$ using a combination of (diacetoxyiodo)benzene (DIB) and lithium bromide in acetonitrile, which led to dibromo derivative $7 \mathbf{a}$ with $91 \%$ yield (Scheme 2). Running the same reaction in ethanol or in a water/acetonitrile mixture triggered the oxybromination process yielding ethoxy- and hydroxy adducts $\mathbf{6 a}$ and $\mathbf{6 a}$ ', respectively, with satisfying yields. This reactivity switch validated the second half of our premise but despite extensive screening, ${ }^{12}$ geranyl acetate, because of the deactivation of the internal double bond, seemed unsuitable to probe the triggering of the cyclization process.

Scheme 2 Solvent effect in the DIB-mediated bromination of geranyl acetate.

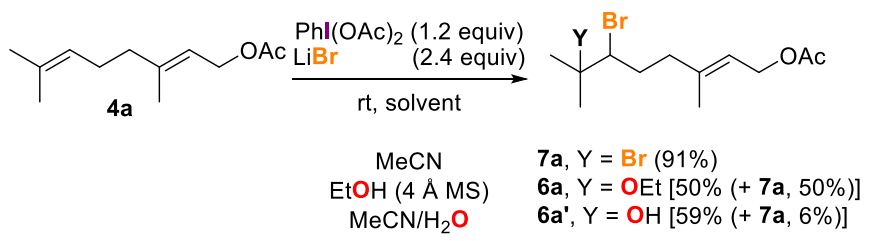

In order to circumvent this hurdle, we decided to focus our attention on the reactivity of the electron-rich homogeranylbenzene 4b (Table 1), that has been shown to cyclize more readily towards mono- $(\mathbf{5 b})$ and/or tricyclic $(\mathbf{8 b})$ adducts under a variety of conditions. ${ }^{7,8}$ 
Table 1 Optimization of the iodine(III)-mediated dibromination, oxybromination and bromocyclization of homogeranylbenzene $4 b^{a}$

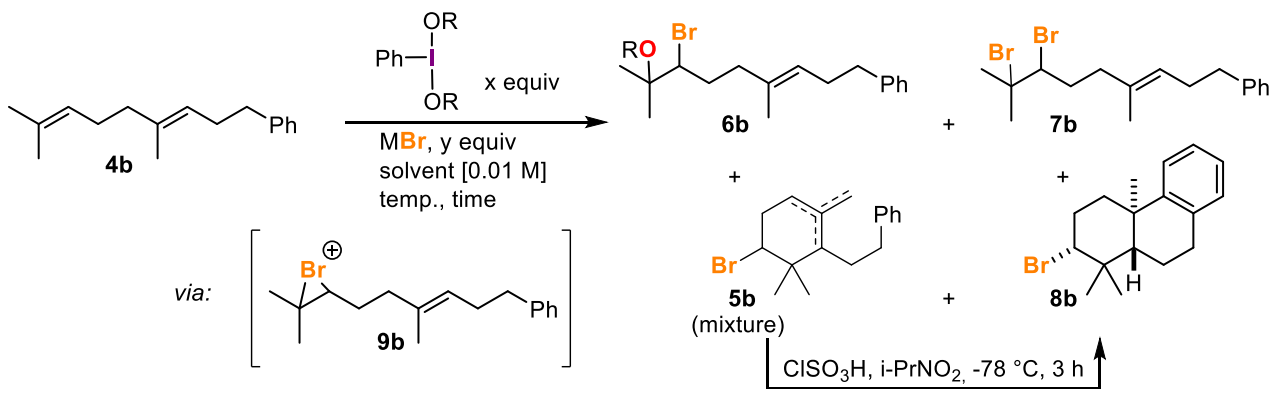

\begin{tabular}{|c|c|c|c|c|c|c|c|c|c|c|}
\hline entry & $\mathrm{R}$ (x equiv) & M (y equiv) & solvent & {$[\mathrm{M}]^{b}$} & temp & $\begin{array}{l}\text { addition } \\
\text { time }\end{array}$ & $\begin{array}{c}\mathbf{5 b}, \\
\text { yield } \% c\end{array}$ & $\begin{array}{c}\mathbf{6 b}, \\
\text { yield \%c }\end{array}$ & $\begin{array}{c}\mathbf{7 b}, \\
\text { yield } \%{ }^{c}\end{array}$ & $\begin{array}{c}\mathbf{8 b} \\
\text { yield } \%^{c}\end{array}$ \\
\hline 1 & Ac (1.2) & $\mathrm{Li}(2.4)$ & $\mathrm{MeCN}$ & 0.05 & $0^{\circ} \mathrm{C}$ & $5 \min ^{d}$ & - & - & 63 & - \\
\hline 2 & Ac (1.1) & Li (1.1) & $\mathrm{MeCN}$ & 0.02 & $0{ }^{\circ} \mathrm{C}$ & $10 \mathrm{~min}$ & - & - & 46 & - \\
\hline 3 & $\mathrm{C}(\mathrm{O}) \mathrm{CF}_{3}(1.2)$ & $\mathrm{Li}(1.1)$ & $\mathrm{MeCN}$ & 0.01 & $0{ }^{\circ} \mathrm{C}$ & $30 \mathrm{~min}$ & 17 & - & $-^{e}$ & 22 \\
\hline 4 & $\mathrm{C}(\mathrm{O}) \mathrm{CF}_{3}(1.2)$ & $\mathrm{Me}_{3} \mathrm{Si}$ (1.1) & $\mathrm{MeCN}$ & 0.01 & $0{ }^{\circ} \mathrm{C}$ & $20 \mathrm{~min}$ & 41 & - & Traces $^{f}$ & $15(46)$ \\
\hline 5 & $\mathrm{C}(\mathrm{O}) \mathrm{CF}_{3}(1.2)$ & $\mathrm{Me}_{3} \mathrm{Si}$ (1.1) & $\mathrm{MeCN}$ & 0.01 & $0^{\circ} \mathrm{C}$ & $30 \mathrm{~min}$ & 16 & - & $3^{f}$ & $19^{g}$ \\
\hline 6 & $\mathrm{C}(\mathrm{O}) \mathrm{CF}_{3}(1.2$ & $\mathrm{Et}_{3} \mathrm{Si}(1.1)$ & $\mathrm{MeCN}$ & 0.01 & $0^{\circ} \mathrm{C}$ & $20 \mathrm{~min}$ & 33 & - & $f$ & $15^{g}$ \\
\hline 7 & $\mathrm{C}(\mathrm{O}) \mathrm{CF}_{3}(1.2)$ & $\mathrm{Et}_{3} \mathrm{HN}$ & $\mathrm{MeCN}$ & 0.01 & $0{ }^{\circ} \mathrm{C}$ & $10 \mathrm{~min}$ & 15 & 6 & $-f$ & 20 \\
\hline 8 & $\mathrm{C}(\mathrm{O}) \mathrm{CF}_{3}(1.2)$ & Bu4N (1.1) & $\mathrm{MeCN}$ & 0.01 & $0{ }^{\circ} \mathrm{C}$ & $10 \mathrm{~min}$ & 6 & 44 & $f$ & 8 \\
\hline 9 & $\mathrm{C}(\mathrm{O}) \mathrm{CF}_{3}(1.2)$ & $\mathrm{Bu}_{4} \mathrm{~N}(1.1)$ & $\mathrm{MeCN}$ & 0.04 & $0{ }^{\circ} \mathrm{C}$ & $5 \mathrm{~min}$ & - & 60 & - & - \\
\hline 10 & $\mathrm{C}(\mathrm{O}) \mathrm{CF}_{3}(1.2)$ & $\mathrm{Et}_{3} \mathrm{Si}(1.1)$ & $\mathrm{MeNO}_{2}$ & 0.01 & $0^{\circ} \mathrm{C}$ & $10 \mathrm{~min}$ & 27 & 4 & $f$ & 20 \\
\hline 11 & $\mathrm{C}(\mathrm{O}) \mathrm{CMe}_{3}(1.2)$ & $\mathrm{Et}_{3} \mathrm{Si}(1.1)$ & $\mathrm{MeNO}_{2}$ & 0.01 & $0{ }^{\circ} \mathrm{C}$ & $10 \mathrm{~min}$ & 24 & - & $f$ & 24 \\
\hline 12 & $\mathrm{C}(\mathrm{O}) \mathrm{CMe}_{3}(1.2)$ & $\mathrm{Et}_{3} \mathrm{Si}(1.1)$ & EtNO$_{2}$ & 0.04 & $-78^{\circ} \mathrm{C}$ & $10 \mathrm{~min}$ & N/A ${ }^{h}$ & - & - & (54) \\
\hline 13 & $\mathrm{C}(\mathrm{O}) \mathrm{CMe}_{3}(1.2)$ & $\mathrm{Et}_{3} \mathrm{Si}(1.1)$ & $\mathrm{EtNO}_{2}$ & 0.04 & $-78^{\circ} \mathrm{C}$ & $10 \mathrm{~min}$ & $\mathrm{~N} / \mathrm{A}^{h}$ & - & - & $(67)^{i}$ \\
\hline
\end{tabular}

${ }^{a} \mathrm{~A}$ solution of $\mathrm{MBr}[2 \mathrm{C}]$ was slowly added to a solution of $\mathbf{4 b}[2 \mathrm{C}]$ containing the iodine(III) reagent. ${ }^{b}$ Resulting concentration after addition. ${ }^{c}$ Isolated yields; for $\mathbf{8 b}$ overall yield after re-cyclization of $\mathbf{5 b}$ with $\mathrm{ClSO}_{3} \mathrm{H}$ is given in parenthesis. ${ }^{d} \mathrm{Direct}$ addition of $\mathrm{LiBr}$ and with $4 \AA$ AS. ${ }^{e}$ And $7 \%$ of $\mathbf{1 0 b} .{ }^{f}$ And traces of $\mathbf{1 0 b} .{ }^{g}$ And $8 \%$ of $\mathbf{1 1 b} .{ }^{h}$ The crude reaction mixture $(5: 2: 1$ ratio of tetra-, tri-, disubstituted olefins) was recyclized without purification. ${ }^{i}$ Recyclization with $\mathrm{MeSO}_{3} \mathrm{H}, \mathrm{dr}=6: 1$.

We therefore screened numerous parameters ${ }^{12}$ in order to generate the initial bromonium intermediate $\mathbf{9 b}$ and selectively orientate its evolutions towards one of the many possible adducts $(\mathbf{5 - 8}, \mathbf{1 0}$ and 11). ${ }^{13}$ As with geranyl acetate, the combination of DIB and $\mathrm{LiBr}$ in $\mathrm{MeCN}$, mainly led to dibromo compound $\mathbf{7 b}$ in $63 \%$ yield (Table 1, entry 1). ${ }^{14}$ Halving the amount of bromide and adding it slowly as the last reagent in order to prevent dibromination only led to a decrease in yield, without changing the reaction course (Table 1, entry 2). However, using this protocol and replacing the DIB by its trifluoroacetoxy analog (PIFA) diverted the reactivity toward bromocyclization giving $\mathbf{5 b}$ (as a mixture of isomers) and tricycle $\mathbf{8 b}$ in a $39 \%$ cumulated yield (Table 1, entry 3 ). This result could be further improved by using the more soluble TMSBr to give $41 \%$ of $\mathbf{5 b}$ and $15 \%$ of $\mathbf{8 b}$ (Table 1, entry 4 ). Treatment of the mixture of brominated cyclohexenes $\mathbf{5 b}$ with chlorosulfonic acid in 2-nitropropane at $-78^{\circ} \mathrm{C}^{7,8}$ to give $\mathbf{8 b}$ led to a cumulated yield of tricyclic adduct of $46 \%$. Increasing the addition time (Table 1, entry 5 ) or exchanging trimethylsilylbromide for triethylsilylbromide (Table 1, entry 6) mostly led to complex mixtures of adducts, including allylbromide $\mathbf{1 0 b}$ and cyclopentene $\mathbf{1 1 b}{ }^{13}$ When alkylammonium bromide salts were used, the acyloxybromination pathway was also observed (Table 1, entries 7 and 8), with $\mathbf{6 b}$ becoming the major product when tetrabutylammonium bromide was employed (Table 1 , entry 8 ). This could be further improved by increasing slightly the concentration and the addition rate, to obtain $60 \%$ of $\mathbf{6 b}$ (Table 1, entry 9). Running the reaction in nitromethane with $\mathrm{TESBr}$ steered the reactivity back towards cyclization (Table 1, entry 10) and using the bulkier bis(tert-butylcarbonyloxy)iodobenzene completely suppressed the oxybromination pathway (Table 1, entry 11). In order to perform the reaction at a lower temperature $\left(-78^{\circ} \mathrm{C}\right)$, nitroethane was employed instead of nitromethane. This prevented the formation of $\mathbf{1 0 b}$ and directly submitting the crude product to $\mathrm{ClSO}_{3} \mathrm{H}$ treatment gave $\mathbf{8 b}$ in $54 \%$ yield over two steps (Table 1, entry 12). Eventually, performing the same sequence with $\mathrm{MeSO}_{3} \mathrm{H}$ in the second step improved the yield up to $67 \%$ in a $6: 1$ diastereomeric ratio (Table 1, entry 13). ${ }^{15}$ This thorough optimization helped define three sets of conditions to selectively access dibromo- oxybromo- and cyclobromo-derivatives. First, the scope of the former two processes was evaluated.

In addition to the above mentioned results on geranyl acetate $4 \mathbf{a}$ and homogeranylbenzene $\mathbf{4 b}$, the combination of DIB and LiBr selectively triggered the dibromination of $o$-homogeranylanisole $\mathbf{4 c}$ and geranylbenzene $4 \mathbf{d}$ to give $\mathbf{7 a - d}$ in good to excellent yields (Table 2, entries 1-4). The same protocol could be applied to geraniol $4 \mathbf{e}$ to give $7 \mathbf{e}$ in $63 \%$ yield without any detectable oxidation of the free alcohol (Table 2, entry 5). Finally, the more challenging bis(benzyloxycarbamate)-guanidine $\mathbf{4 f}$ could be selectively dibrominated to yield $7 \mathbf{f}$ by using a reverse addition protocol at $-78{ }^{\circ} \mathrm{C}$ (Table 2, entry 6). The same substrates were also submitted to the $\mathrm{PIFA} / n-\mathrm{Bu} 4 \mathrm{NBr}$ combination to give the $\alpha$-bromo trifluoroacetyl adducts 6 . Geranyl acetate led to $\mathbf{6 a}$ "' and geraniol to $6 \mathbf{e}$ in $77 \%$ and 
$57 \%$ yield, respectively (Table 2, entries 1 and 5). In addition to $\mathbf{4 b}$, the other aryl derivatives $\mathbf{4} \mathbf{c}$ and $\mathbf{4 d}$ reacted equally well to give the oxybrominated adducts in $56 \%$ and $64 \%$ yield (Table 2, entries 3 and 4). Only guanidine $\mathbf{4 f}$ reacted sluggishly to yield the desired trifluoroacetoxy adduct $\mathbf{6 f}$ in only $25 \%$ yield (Table 2, entry 6) along with $13 \%$ of $7 \mathbf{f}$ and $31 \%$ of cyclic guanidine $\mathbf{1 2}$ (see Scheme 5). Finally, it was demonstrated that selective cleavage of the trifluoroacetoxy group of $\mathbf{6} \mathbf{b}$ could be achieved with $\mathrm{NaBH}_{4}$ to give the corresponding bromohydrine with $79 \%$ yield. ${ }^{12}$

Table 2 Scope of the dibromination and the trifluoroacetoxybromination.

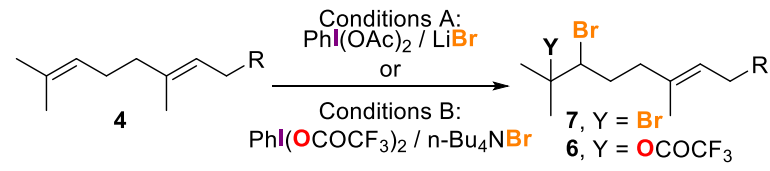

$\begin{array}{clcc}\text { entry } & \text { 4, R } & \mathbf{7}, \text { yield } \%^{a} & \mathbf{6}, \text { yield } \%^{b} \\ 1 & \text { 4a, OAc } & 91 & 77 \\ 2 & \text { 4b, Bn } & 63 & 60 \\ 3 & \text { 4c, } o-\mathrm{MeOBn} & 52 & 56 \\ 4 & \mathbf{4 d}, \mathrm{Ph} & 55 & 64 \\ 5 & \mathbf{4}, \mathrm{OHe} & 63 & 57 \\ 6 & \mathbf{4 f}, \mathrm{NHC}(\mathrm{NZ}) \mathrm{NHZ} & 52^{c} & 25^{d}\end{array}$

${ }^{a}$ Isolated yields for conditions $\mathrm{A}$ : $\mathrm{PhI}(\mathrm{OAc})_{2}$ (1.2 equiv), $\mathrm{LiBr}$ (2.4 equiv), $4 \AA \mathrm{MS}$ in $\mathrm{MeCN}$, at $0{ }^{\circ} \mathrm{C}$ for 5 min ${ }^{b}$ Isolated yields for conditions $\mathrm{B}$ : $\mathrm{PhI}\left(\mathrm{OCOCF}_{3}\right)_{2}$ (1.2 equiv) $n$ - $\mathrm{Bu} 4 \mathrm{NBr}(2.4$ equiv) in $\mathrm{MeCN}$, at $0{ }^{\circ} \mathrm{C}$ for $5 \mathrm{~min}{ }^{c} \mathrm{At}-78{ }^{\circ} \mathrm{C}$, using $\mathrm{TESBr}$ instead of $\mathrm{LiBr} .{ }^{d} \mathrm{At}-78{ }^{\circ} \mathrm{C},+13 \%$ of $\mathbf{6 f}$ and $31 \%$ of $\mathbf{1 2}$.

We then turned our attention towards the third protocol and studied the cyclization of several homogeranyl and geranyl derivatives. First, homogeranylarenes were reacted under the optimized conditions, followed by treatment with sulfonic acid or with tin(IV) chloride, ${ }^{15}$ to provide the corresponding tricycles (Scheme 3). Para-toluene $\mathbf{4 g}$, para-anisole $\mathbf{4 h}$ and ortho-anisole $\mathbf{4 c}$ derivatives led to the desired bromo-octahydrophenanthrenes $\mathbf{8 g}, \mathbf{8 h}$ and $\mathbf{8 c}$ with $40 \%$ to $60 \%$ yields and moderate to good diastereoselectivities.

Scheme 3 Bromocyclization of homogeranyl- and homofarnesylarenes.

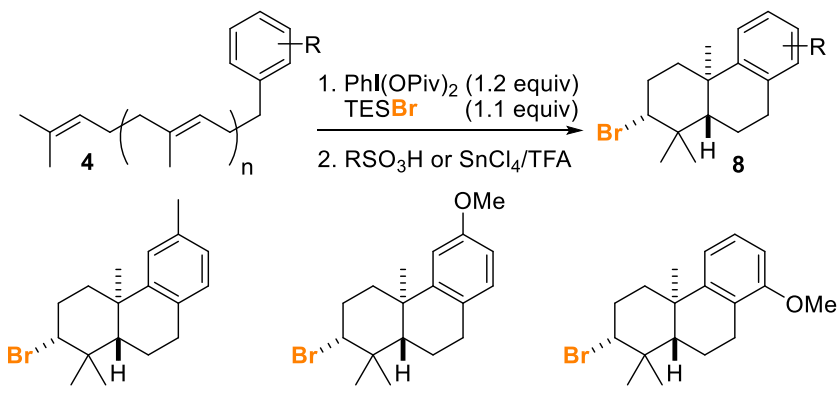

$8 \mathrm{~g}(54 \%, \mathrm{dr}=6: 1)$

$8 \mathrm{~h}(40 \%, \mathrm{dr}>20: 1)$

$8 \mathrm{c}(60 \%, \mathrm{dr}=2: 1)$

from $\mathbf{4 g}, \mathrm{n}=1, \mathrm{R}=p-\mathrm{Me}$ from $\mathbf{4 h}, \mathrm{n}=1, \mathrm{R}=p-\mathrm{MeO}$

from $4 c, n=1, R=o-M e$

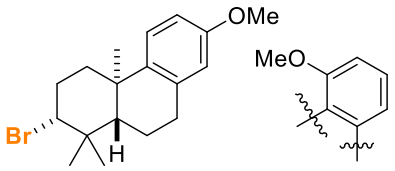

$8 \mathbf{i}(45 \%, d r>20: 1)+8 \mathbf{i}^{\prime}(28 \%, d r>20: 1)$ from $4 \mathbf{i}, \mathrm{n}=1, \mathrm{R}=m-\mathrm{MeO}$

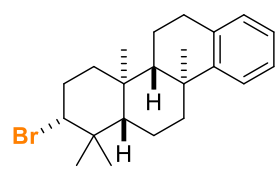

$8 \mathbf{j}(18 \%, d r=3: 1)$ from $4 j, n=2, R=H$
The reaction proceeded even better with meta-anisyl substrate $\mathbf{4 i}$, although the two adducts arising from para and ortho addition (8i $+\mathbf{8} \mathbf{i} '=73 \%$ yield) were formed. Finally, homofarnesylbenzene $\mathbf{4 j}$ was reacted to give bromotetracycle $\mathbf{8 j}$ in a low but satisfying yield, considering that one $\mathrm{C}-\mathrm{Br}$ and three $\mathrm{C}-\mathrm{C}$ bonds are formed in the sequence.

In the case of phenolic homogeranyl derivatives, $\mathrm{PhI}(\mathrm{OPiv})_{2}$-mediated bromocyclization gave good $(59 \%$ to $65 \%)$ overall yield of bromo-cyclized products, ${ }^{16}$ the distribution of which varied depending on the initial substitution pattern (Scheme 4). Starting from ortho-phenol $\mathbf{4 k}$, in addition to the monocyclic cyclohexenes $\mathbf{5 k}$ and the expected tricycle 8k, compound $\mathbf{1 3}$ embedding a sevenmembered ring was also isolated. ${ }^{17}$ For meta-phenol $\mathbf{4 l}$, the cyclohexenes $\mathbf{5 l}$ were obtained in $36 \%$ yield and the two brominated polycycles arising from para and ortho addition $(\mathbf{8 1}+\mathbf{8 1}$ ' $=23 \%$ yield $)$ were also formed.

Scheme 4 Bromocyclization of homogeranylphenols.
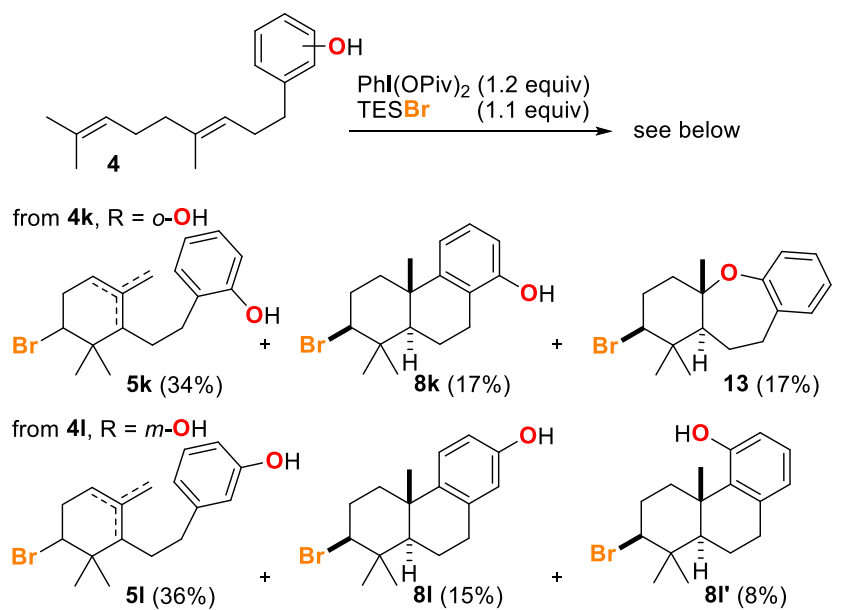

Finally, the behavior of geranyl compounds was explored (Scheme 5). Geranyl-benzene 4d led to bromocyclohexenes $5 \mathbf{d}$ in $43 \%$ yield as a mixture of endo/exo adducts. ${ }^{18}$ The analogous cyclohexenes $\mathbf{5 m}$ were obtained in slightly higher yield (51\%) from $o$-geranylanisole $\mathbf{4 m}$ along with $24 \%$ of bromo-hexahydroxanthene 14 arising from a cascade cyclization and concomitant loss of a methyl group.

\section{Scheme 5 Bromocyclization of geranyl derivatives.}
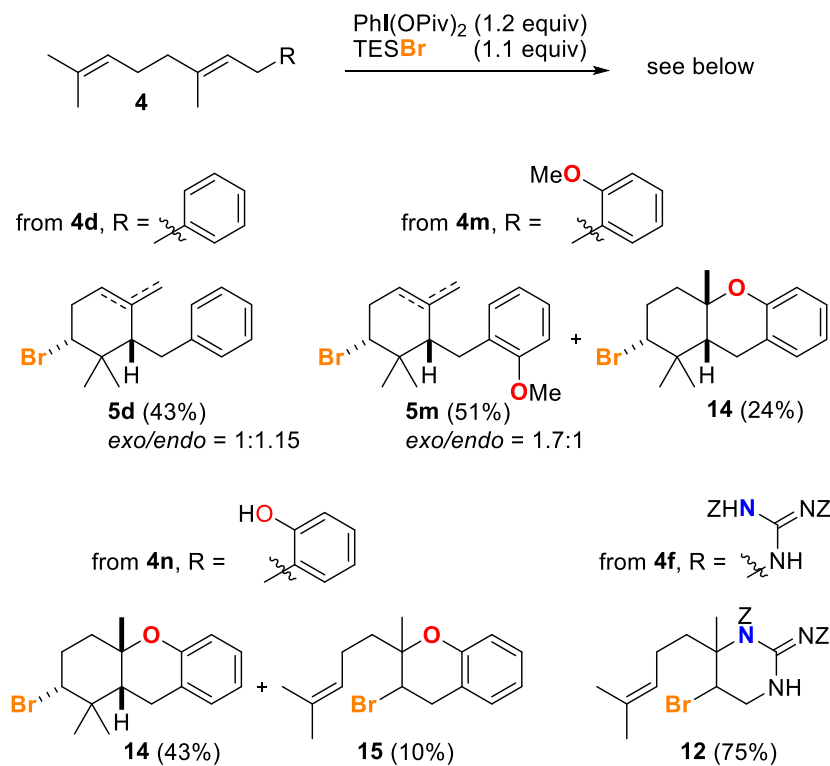<smiles>[Z2]N=C1NCC(Br)C([Z])(CCC=C(C)C)N1</smiles> 
As could be expected, this isocymobarbatol-like adduct became the major product when $o$-geranylphenol $\mathbf{4 n}$ was subjected to the $\mathrm{PhI}(\mathrm{OPiv})_{2} / \mathrm{TESBr}$ combination. 3-Bromochromane 15, resulting from a phenoxybromination of the internal double bond, was also observed as a minor adduct. This change in chemoselectivity might hint at an active participation of the heteroatom in the cyclization process, presumably via initial ligand exchange between the phenol and the ester on the hypervalent iodine center, followed by oxyhalogenation of the proximal double bond. This was further exemplified by the reaction of guanidine $\mathbf{4 f}$ which smoothly led to $\mathbf{1 2}$ with $75 \%$ yield. Indeed, it is the only substrate that we studied for which the reaction mainly occurred on the internal double bond.

Overall we have shown that using a combination of a (bisacyloxy)iodobenzene and a bromide source three different electrophilic brominations of terpenoids with different outcomes could be triggered. Simple adjustments in the nature of the reagents (all commercially available) and the procedure (temperature, rate and order of addition) could steer the reactivity towards dibromination, oxy-bromination or bromocyclization, including cascade processes. This strategy grants access to various motifs that can be found in several families of natural products. Studies in this direction as well as the implementation of this methodology for other halides are currently being pursued.

\section{ASSOCIATED CONTENT}

\section{Supporting Information}

Supporting Information contains experimental procedures, analytical data and copies of NMR spectra for all new compounds (pdf) and crystallographic data for $\mathbf{5 d , ~} \mathbf{8 b}$ and $\mathbf{1 3}$ (cif). This material is available free of charge via the Internet at http://pubs.acs.org.

\section{AUTHOR INFORMATION}

\section{Corresponding Author}

*kevin.cariou@cnrs.fr

\section{Notes}

The authors declare no competing financial interests.

\section{ACKNOWLEDGMENT}

The authors thank CNRS and ICSN, for financial support. T. D. G. thanks ICSN for a PhD fellowship.

\section{REFERENCES}

(1) (a) Gribble, G. W. J. Nat. Prod. 1992, 55, 1353. (b) Wang, B.-G.; Gloer, J. B.; Ji, N.-Y.; Zhao, J.-C. Chem. Rev. 2013, 113, 3632. (c) Chung, W.-J.; Vanderwal, C. D. Angew. Chem., Int. Ed. 2016, 55, 4396.

(2) Gribble, G. W. J. Chem. Educ. 2004, 81, 1441

(3) (a) Butler, A.; Carter-Franklin, J. N. Nat. Prod. Rep. 2004, 21, 180. (b) Vaillancourt, F. H.; Yeh, E.; Vosburg, D. A.; Garneau-Tsodikova, S.; Walsh, C. T. Chem. Rev. 2006, 106, 3364. (c) Agarwal, V.; Miles, Z. D.; Winter, J. M.; Eustaquio, A. S.; El Gamal, A. A.; Moore, B. S. Chem. Rev. 2017, 117, 5619

(4) Isolation: (a) Kubanek, J.; Prusak, A. C.; Snell, T. W.; Giese, R. A.; Hardcastle, K. I.; Fairchild, C. R.; Aalbersberg, W.; Raventos-Suarez, C.; Hay, M. E. Org. Lett. 2005, 7, 5261. Synthetic approach: (b) Lin, H.; Pochapsky, S. S.; Krauss I. J. Org. Lett. 2011, 13, 1222.

(5) (a) Hogberg, H.-E. ; Thornson, R. H. J. Chem. Soc., Perkin Trans. 1, 1976, 1696. (b) McConnell, O. J. ; Hughes, P. A. Targett, N. M. Phytochemistry 1982, 21, 213.
(6) Wall, M. E. ; Wani, M. C.; Manikumar, G.; Taylor, H.; Hughes, T. J.; Gaetano, K.; Gerwick, W. H.; McPhail, A. T.; McPhail, D. R. J. Nat. Prod. 1989, 52, 1092 .

(7) (a) Snyder, S. A.; Treitler, D. S. Angew. Chem., Int. Ed. 2009, 48, 7899. (b) Snyder, S. A.; Treitler, D. S.; Brucks, A. P. J. Am. Chem. Soc. 2010 132, 14303. (c) Snyder, S. A.; Treitler, D. S.; Schall, A. Tetrahedron 2010, 66, 4796. (d) Snyder, S. A.; Treitler, D. S.; Brucks, A. P. Aldrichimica Acta. 2011, 44, 27. (e) Snyder, S. A.; Brucks, A. P.; Treitler, D. S. Moga, I. J. Am. Chem. Soc. 2012, 134, 17714. (f) Shen, M.; Kretschmer, M.; Brill, Z. G.; Snyder, S. A. Org. Lett. 2016, 18, 5018.

(8) For other strategies aimed at the halocyclization of polyenes, including asymmetric versions see: (a) Sakakura, A.; Ukai, A.; Ishihara, K. Nature 2007, 445, 900. (b) Sawamura, Y.; Nakatsuji, H.; Sakakura, A.; Ishihara, K. Chem. Sci. 2013, 4, 4181. (c) Sawamura, Y.; Nakatsuji, H.; Akakura, M.; Sakakura, A.; Ishihara, K. Chirality 2014, 26, 356. (d) Sakakura, A.; Ishihara, K. Chem. Rec. 2015, 15, 728. (e) Samanta, R. C.; Yamamoto H. Chem. Eur. J. 2015, 21, 11976. (f) Recsei, C.; McErlean, C. S. P. Aust. J. Chem. 2015, 68, 555. (g) Sawamura, Y.; Ogura, Y.; Nakatsuji, H.; Sakakura, A.; Ishihara, K. Chem. Commun. 2016, 52, 6068. (h) Samanta, R. C.; Yamamoto H. J. Am. Chem. Soc. 2017, 139, 1460.

(9) (a) Nocquet-Thibault, S.; Retailleau, P.; Cariou, K.; Dodd, R. H. Org. Lett. 2013, 15, 1842. (b) Nocquet-Thibault, S.; Minard, C.; Retailleau, P.; Cariou, K.; Dodd, R. H. Tetrahedron 2014, 70, 6769. (c) Nocquet-Thibault, S.; Rayar, A.; Retailleau, P.; Cariou, K.; Dodd, R. H. Chem.-Eur. J. 2015 , 21, 14205. (d) Daniel, M.; Blanchard, F.; Nocquet-Thibault, S.; Cariou, K.; Dodd, R. H. J. Org. Chem. 2015, 80, 10624. (e) Beltran, R.; Nocquet-Thibault, S.; Blanchard, F.; Dodd, R. H.; Cariou, K. Org. Biomol. Chem. 2016 , 14,8448 .

(10) For seminal and recent papers about iodine(III) mediated bromination, see (a) Amey, R. L.; Martin, J. C. J. Org. Chem. 1979, 44, 1779. (b) Braddock, D. C.; Cansell, G.; Hermitage, S. A.; White, A. J. P. Chem. Commun. 2006, 1442. (c) Fabry, D. C.; Stodulski, M.; Hoerner, S.; Gulder, T. Chem.Eur. J. 2012, 18, 10834. (d) Stodulski, M.; Goetzinger, A.; Kohlhepp, S. V.; Gulder, T. Chem. Commun. 2014, 50, 3435. (e) Ulmer, A.; Stodulski, M.; Kohlhepp, S. V.; Patzelt, C.; Pçthig, A.; Bettray, W.; Gulder, T. Chem-Eur. J. 2015, 21, 1444. (f) Patzelt, C.; Pöthig, A.; Gulder, T. Org. Lett. 2016, 16, 3466. For a highlight on the specificity of iodine(III)- mediated halogenation, see: (g) Arnold, A. M.; Ulmer, A.; Gulder, T. Chem. - Eur. J. 2016, 22,8728

(11) For general reviews, see: (a) Brown, M.; Farid, U.; Wirth, T. Synlett 2013, 424. (b) Singh, F. V.; Wirth, T. Chem. - Asian J. 2014, 9, 950. (c) Yoshimura, A.; Zhdankin, V. V. Chem. Rev. 2016, 116, 3328.

(12) See Supporting Information for details.

(13) In addition to compounds 5-8, direct elimination can lead to allylic bromide 10b and cyclopentene 11b. This latter motif can be found in debromophycolide $\mathrm{A}$ and its formation was proposed to stem from debromination followed by ring contraction (see ref $4 a$ ).

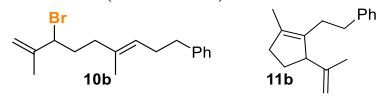

(14) Along with products resulting from dibromination of the internal double bond $(9 \%)$ and dibromination of both bonds $(9 \%)$.

(15) The relative configuration of $\mathbf{8 b}$ is consistent with the literature (e.g. refs $4 \& 5$ ) and was confirmed by X-ray crystallography (CCDC 1550946). (16) Recyclization protocols only led to very complex mixture of products. (17) The structure and relative configuration of $\mathbf{1 3}$ were confirmed by Xray crystallography (CCDC 1550947). A brominated 6-7 bicycle scaffold can be found in the aplysistatin natural products family, see: (a) Pettit, G. R.; Herald, C. L.; Allen, M. S.; Von Dreele, R. B.; Vanell, L. D.; Kao, J. P. Y.; Blake, W. J. Am. Chem. Soc. 1977, 99, 262. (b) Von Dreele, R. B.; Kao, J. P. Y. Acta Crystallogr., Sect. B: Struct. Crystallogr. Cryst. Chem. 1980, 36, 2695. (c) Capon, R.; Ghisalberti, E. L.; Jefferies, P. R.; Skelton, B. W.; White, A. H. Tetrahedron 1981, 37, 1613. (d) Kuniyoshi, M.; Marma, M. S.; Higa, T.; Bernardinelli, G.; Jefford, C. W. J. Nat. Prod. 2001, 64, 696. (e) Paul, V. J.; Fenical, W. Tetrahedron Lett. 1980, 21, 2787.

(18) The structure of endo-5d was confirmed by X-ray crystallography (CCDC 1550946) 


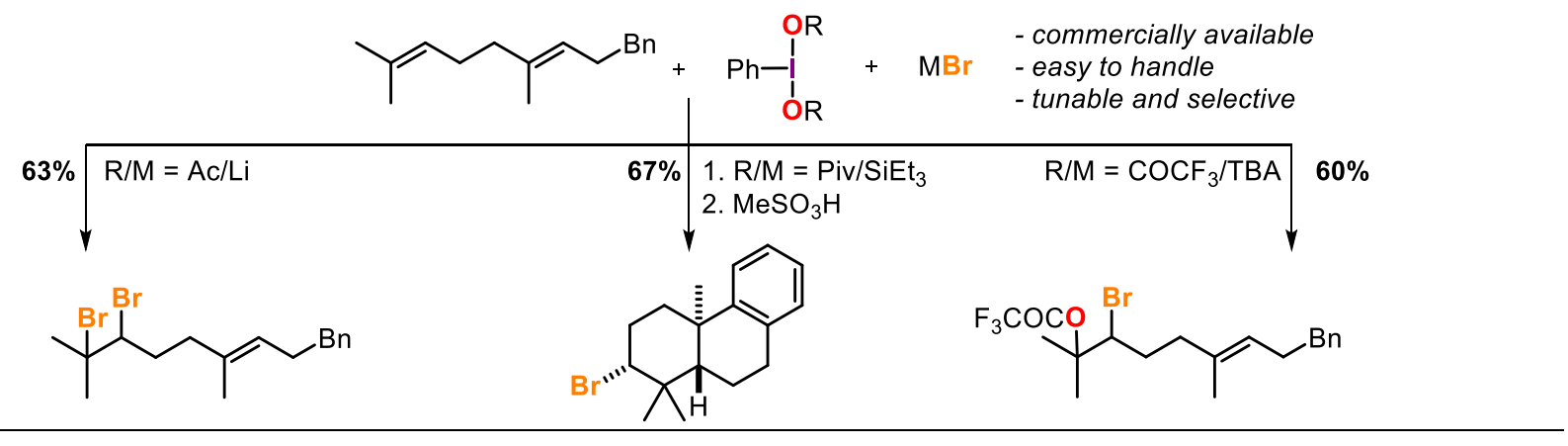

5 